\title{
$\operatorname{GaAs}(001)$ 表面近傍の結晶欠陥の制御による 表面 Fermi 準位の制御
}

\author{
廣田幸弘・前田文彦・渡辺義夫・荻野俊郎 \\ NTT 基礎研究所 $巴 243-01$ 神奈川県厚木市森の里若宮 3-1 \\ （1997 年 3 月 4 日受付；1997 年 6 月 20 日掲載決定）
}

\section{Control of Surface Fermi Level Position by Controlling Crystal Defects near the GaAs(001) Surface}

\author{
Yukihiro Hirota, Fumihiko Maeda, Yoshio Watanabe and Toshio Ogino \\ NTT Basic Research Laboratories \\ 3-1 Morinosato-Wakamiya, Atsugi, Kanagawa 243-01
}

(Received March 4, 1997; Accepted June 20, 1997)

\begin{abstract}
The effects of crystal defects near the surface on the position of surface Fermi level (EF) are investigated using photoluminescence (PL) measurements and synchrotron radiation photoelectron spectroscopy (SRPES). For the lightly Sidoped GaAs(001) surface, PL measurements reveal that after heating to $500^{\circ} \mathrm{C}$ a layer with lower PL peak intensities related to gallium vacancies than those of the bulk exists just under the thermal degraded layer. SRPES shows that EFs moves upward to $1.1-1.17 \mathrm{eV}$ above the valence band maximum when this thermal degraded layer is removed by chemical etching. The excess arsenic on the surface, which is formed by rinsing the etched surface with deoxygenated and deionized water, is evaporated by heating in ultra-high vacuum (UHV). After evaporation of excess arsenic on the surface by heating, the etching-depth dependence of $E_{F S}$ for a sample pre-heated in UHV correlates with the existence of this defect concentration layer. These results suggest that the position of $E_{F s}$ for $\mathrm{GaAs}(001)$ surface is strongly influenced by crystal defects near the surface.
\end{abstract}

\section{1. は じめに}

これまでに化合物半導体の表面・界面を制御するため に様々な試みが行われてきた。これは，表面・界面の電 子状態を制御することが, 従来の電子および光デバイス 特性の向上をもたらすばかりか, 新しい機能デバイスを 創出する上にも重要なためである。しかし，これまでの 表面・界面の電気・光学的特性を制御する様々な試み は, 十分に満足のいくものとなってはいない。 InP 結晶では，表面準位密度が比較的小さく，金属一 絶縁体-半導体（MIS）型素子を用いた検討がなされ, その電気特性を通じ, 表面近傍に誘起される結晶欠陥が, 表面準位の形成および表面 2 次元電子の散乱体として作 用することが明らかとなっている ${ }^{12)}$ 。一方, GaAs (001) 表面では, 高密度の表面準位により, 表面フェルミ準位
（EFs）がミッドギャップ近傍に強くピンニングされるた め, $\mathrm{E}_{\mathrm{FS}}$ と表面近傍の結晶欠陥を関連づける議論は十分 にはなされていない。

我々は, $\mathrm{GaAs}(001)$ 表面においても表面近傍の結晶 欠陥が InP 表面と同様に表面・界面電子物性に大きな 影響を与えるものと考え, 従来と異なる低エネルギー による表面清浄化法として脱溶存酸素・超純水洗浄 （DODIW）法による表面の清浄化を提案してきた ${ }^{3 \sim 9)}$ 。 これは, 従来のイオンあるいはプラズマ等を用いた表面 清浄化法ではプロセス時の結晶欠陥の導入が避けられ ず3), 表面近傍の結晶欠陥の電気的光学的影響を十分に 把握できないためである。

DODIW 処理の特徴は, 以下のようにまとめられる。

1. 電気化学反応を用いるために, 低エネルギー処理で ある。 
2. 反応は最表面に限定される。

3. $\mathrm{GaAs}$ 表面では $\mathrm{Ga}$ および As 酸化物を除去できる。

4. 極低溶存酸素濃度（1～5 ppb）の場合に, 表面の酸 化物の除去後, 基板構成元素の $\mathrm{Ga}$ 原子の純水中へ の溶解反応が優勢となり, 表面に過㮃 As 層が形成 される。

この過剩砒素表面は, 結晶成長法, 面方位, ドーピン グ種, ドーピング量, あるいはエッチング表面にかかわ らず形成が可能である。このため, DODIW 処理は, 表 面の酸化物およびプロセスにより誘起される表面欠陥の 影響を取り除き, また, 結晶成長法等の条件に拠らず過 剩砒素表面を形成できるため，GaAs(001) 表面の電子 状態を探る上での有力な手段と考えられる。

我々は, この DODIW 処理を水平ブリッジマン（HB） 成長 $\mathrm{GaAs}(001)$ 表面に適用し，これまでに以下の点を 明らかにしてきた $30,4 ， 8 ， 99$

5. 過剩 As 表面を真空中で加熱した場合には, 350〜 400 ${ }^{\circ} \mathrm{C}$ 以上で表面の過剩砒素が熱脱離し，450-480 ${ }^{\circ} \mathrm{C}$ 以 上で表面構造が, $1 \times 1$ 構造から $2 \times 4$ 構造に変化す る。

6. HB 成長 $\mathrm{GaAs}(001)$ 表面の $\mathrm{E}_{\mathrm{FS}}$ は, 表面構造が $2 \times 4$ 構造を保持していても, 熱処理温度の増大に伴い価 電子帯端（VBM）側に漸近する。

7. 熱処理による $\mathrm{E}_{\mathrm{FS}}$ の VBM への漸近が, 表面近傍の As 元素の解離に伴う結晶欠陥の形成に起因する。

8. HB 成長 $\mathrm{GaAs}(001)$ 表面の表面フェルミ準位は低 $\mathrm{Si}$ ドープよりも高 Si ドープ基板の方が VBM 側にあ る。

以上の 5〜7 項の結果は, $\mathrm{E}_{\mathrm{FS}}$ の位置が表面構造よりも主 に表面近傍の結晶欠陥種および欠陥密度に支配されてい ることを示唆している。

しかし，いまだ不明確な問題が残されている。例えば, 8 項の「低 $\mathrm{Si}$ および高 $\mathrm{Si}$ ドープ基板での $\mathrm{E}_{\mathrm{FS}}$ の位置の 差」, また,「E $\mathrm{E}_{\mathrm{FS}}$ のピンニング位置自体が何により決ま っているか」という問題である。本報告では, $\mathrm{E}_{\mathrm{FS}}$ 自体 のピンニングの原因を明らかにするために，表面近傍の 結晶欠陷と $\mathrm{E}_{\mathrm{FS}}$ の位置について, PL 測定および放射光 光電子分光（SRPES）を用いて検討した結果を示す。ま ず, 熱処理後の HB 成長 GaAs(001) 基板に対する PL スペクトルの深さ依存性より熱処理後の熱劣化層直下に 結晶欠陥密度が未処理の基板よりも小さい領域が存在す ることを示す。次に, SRPES 湘定より求めた熱劣化層 除去後の $\mathrm{GaAs}(001)$ 表面の $\mathrm{E}_{\mathrm{FS}}$ の熱処理温度依存性を 示し, 表面近傍の結晶欠陥密度が減少した場合には表面 バンド曲がりの緩和が生じることを示す。最後にこれら の結果を基に, 表面近傍の結晶欠陥と $\mathrm{E}_{\mathrm{FS}}$ の関係につい
て議論する。

\section{2. 実 験 方 法}

基板には, $\mathrm{HB}$ 成長 $\left(\mathrm{n}(\mathrm{Si}): 1 \times 10^{17} / \mathrm{cm}^{3}, 5 \times 10^{17} / \mathrm{cm}^{3}\right)$ および垂直温度傾斜凝固法 (VGF) 成長 $\left(\mathrm{n}(\mathrm{Si}): 3 \times 10^{16}\right.$ \% $\left.\mathrm{cm}^{3}\right) \mathrm{GaAs}(001)$ 基板を用いた。最初に研磨歪を取り除 くため, $\mathrm{Br}$ ・メタノール溶液による研磨を行った後, $\mathrm{NH}_{4}$ $\mathrm{OH}+\mathrm{H}_{2} \mathrm{O}_{2}+\mathrm{H}_{2} \mathrm{O} （ 1: 1: 20 ）$ 混合液によるエッチング (室温, 2 分間) を行った。エッチング後, 基板はグロ ーブボックス内（窒素雾囲気下）の洗浄セルに移し, DODIW 処理を行った。DODIW 処理後の表面には，過 剩砒素層が形成されている。DODIW 処理時の超純水の 溶存酸素濃度, 超純水の抵抗率, 流量および洗浄時間は, $1 \sim 5 \mathrm{ppb}, 18.2 \mathrm{M} \Omega \cdot \mathrm{cm}, 1.5 \mathrm{~L} / \mathrm{min}, 3$ 時間である。DODIW 処理の詳細は参考文献 5 を参照されたい。

DODIW 処理後の PL 測定用基板は, 大気中での炭素 污染および表面酸化を避けるため窒素封入したトランス ファーボックスを用いて高真空装置に持ち込み熱処理 $\left(450,500,600^{\circ} \mathrm{C}\right)$ を行った。熱処理後に上記エッチ ヤントによるステップエッチングを行い, PL スペクト ルの熱処理温度差およびエッチング深さ依存性を調べ た。エッチング深さの測定には触針式の段差計を用いた。 PL 測定の励起光に He-Neレーザ光 $(633 \mathrm{~nm})$, 検出に は冷却した Ge ディテクターを用いた。試料の測定温度 は液体窒素温度である。PL 測定の深さ分解能は $0.5 \mu \mathrm{m}$ 程度である。

SRPES 测定用基板では，測定時のチャージアップを 防ぐため董面に $\mathrm{AuGeNi} / \mathrm{Au}$ オーミック電極を形成（水 素雾囲気中 $450^{\circ} \mathrm{C}, 2$ 分間）した後に，DODIW 処理お よび高真空下での熱処理 $\left(500^{\circ} \mathrm{C}\right)$ を行った。熱処理後 の基板の表面には，参照用の $\mathrm{Au}$ 電極を設けた。PL 測 定の結果を基に所定の深さまでエッチングした後, 再度 の DODIW 処理を行い窒素雾囲気下で SRPES 装置に持 ち込んだ。

SRPES 測定は, 熱処理後, photovoltaic 効果の影響を 避けるため基板を室温まで冷却した後に行った ${ }^{10,11)}$ 。 SRPES 測定時の真空度は, $2 \times 10^{-9}$ Torr, 入射光電子の エネルギーは $90 \mathrm{eV}$ である。熱処理温度の測定には, 放 射温度計を用いた。 $\mathrm{EFS}_{\mathrm{FS}}$ の位置は, 試料表面の $\mathrm{Au}$ 電極 から求め, VBMの位置は拡大した価電子帯 (VB) スペ クトルとバックグラウンドの外挿線の交点より求めた。

\section{3. 実 験 結 果}

\subsection{PL スペクトルの深さ依存性}

Figs. 1， 2 に，450 および $500^{\circ} \mathrm{C}$ で加熱した低 Si ドー プ $\left(\mathrm{n}(\mathrm{Si}): 1 \times 10^{17} / \mathrm{cm}^{3}\right)$ HB 成長基板の PL スペクトル 


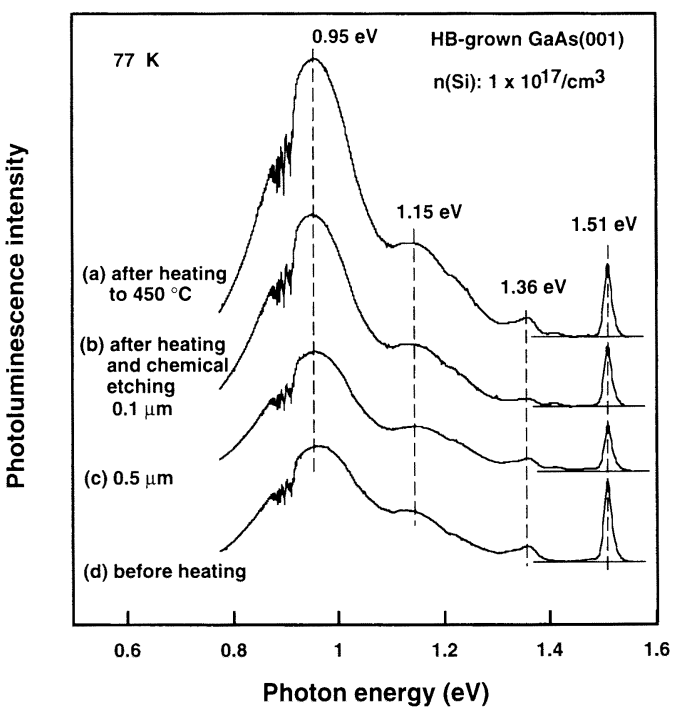

Fig. 1 The depth-profiles of photoluminescence spectra for the DODIW-treated HB-grown GaAs(001) substrate after heating to $450^{\circ} \mathrm{C}$ for $30 \mathrm{~min}$. The surfaces were rinsed with DODIW to remove surface oxides after chemical etching. (a) After heating to $450^{\circ} \mathrm{C}$, (b) after heating and chemical etching to a depth of about 0.1 $\mu \mathrm{m}$ and (c) $0.5 \mu \mathrm{m}$. (d) Before heating.

の樑さ依存性を示す。図中の縦の破線は各スペクトルの ピーク位置を, 水平の実線は PL 強度のバックグラウン ドを示している。各スペクトルの強度は, 熱処理前の PL 測定スペクトル強度で規格化してある（：Fig.1のスペ クトル (d)，および Fig. 2 中のスペクトル (f))。スペ クトル（a）は熱処理直後のPLスペクトルである。他 は，熱処理後エッチングしたPL スペクトルである。図 中に各エッチング深さを示す。

Figs. 1，2より, PL スペクトルの形状およびピーク強 度が，エッチング深さと熱処理温度に依存していること がわかる。Fig.1において，すべてのスペクトルがほぼ 4 つの PLピーク $(1.51,1.36,1.15,0.95 \mathrm{eV})$ を持ち, 熱処理後に表面側で 0.95 および $1.15 \mathrm{eV}$ のピーク強度が 增大していることがわかる。 $0.5 \mu \mathrm{m}$ のエッチング（ス ペクトル (c)) では, $0.95 \mathrm{eV}$ および $1.15 \mathrm{eV}$ の発光ピー ク強度は, ほぼ熱処理前の状態（スペクトル (d)) に回 復している。1.51 eV の PLピークはバンド端ドナー間 の遷移発光 $\left(\mathrm{Si}_{\mathrm{G}}{ }^{+} \mathrm{VB}\right)^{12)}, 1.36 \mathrm{eV}$ の発光ピークは $\mathrm{As}$ 空孔と $\mathrm{Si}$ アクセプター間遷移 $\left(\mathrm{V}_{\mathrm{As}}{ }^{+} \mathrm{Si}_{\mathrm{As}}{ }^{-}\right)^{12,13)}$ と考え られる。1.15 eV の発光ピークは, $\mathrm{Si}$ ドナーと $\mathrm{Ga}$ 空孔 $\left(\mathrm{Si}_{\mathrm{Ga}}{ }^{+} \mathrm{V}_{\mathrm{Ga}}{ }^{3-}\right)^{12,}{ }^{14)}, 0.95 \mathrm{eV}$ の発光ピークは, $\mathrm{V}_{\mathrm{As}} \mathrm{V}_{\mathrm{Ga}}$ と $\mathrm{Si}$ ドナーの複合体 $\left(\mathrm{V}_{\mathrm{As}}{ }^{+} \mathrm{V}_{\mathrm{Ga}^{2}}{ }^{2-}-\mathrm{Si}_{\mathrm{Ga}}{ }^{+}\right)$に起因すると考えら れる ${ }^{15,16)}$ 。

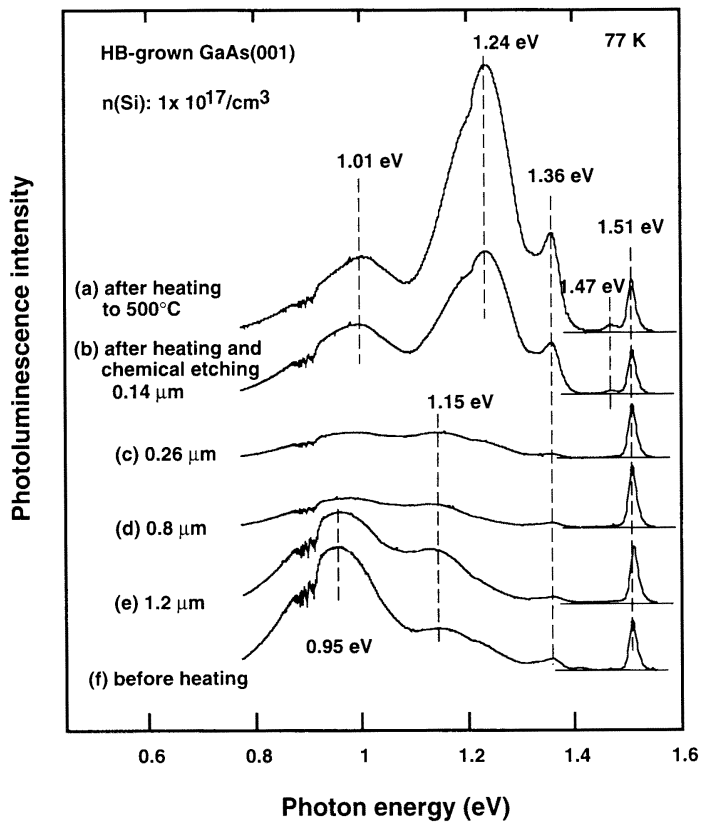

Fig. 2 The depth-profiles of photoluminescence spectra for the DODIW-treated HB-grown GaAs(001) substrate after heating to $500^{\circ} \mathrm{C}$ for $30 \mathrm{~min}$. The surfaces were rinsed with DODIW to remove surface oxides after chemical etching. (a) After heating to $500^{\circ} \mathrm{C}$, (b) after heating and chemical etching to a depth of about 0.14 $\mu \mathrm{m}$, (c) $0.26 \mu \mathrm{m}$, (d) $0.8 \mu \mathrm{m}$, and (e) $1.2 \mu \mathrm{m}$. (f) Before heating.

一方， $500^{\circ} \mathrm{C}$ 熱処理の基板（: Fig. 2）では，PL スペ クトルの深さ分布は Fig. 1 と異なる様相を示す。基板内 部側のスペクトル（e）は，熱処理前のスペクトル（f) と同一の 4 つのピーク $(1.51,1.36,1.15,0.95 \mathrm{eV})$ を 持つものの, 表面側のスペクトル（a）および（b）は， 5 つのピークを示し, そのピークのエネルギー位置も $1.47,1.24,1.01 \mathrm{eV}$ と異なるものが現われる。また, 0.95 $\mathrm{eV}$ の PLピークは，表面側で消失している。 $1.36 \mathrm{eV}$ の PLピーク強度は, 基板側と比較し表面側では増大して いる。スペクトル（c）および（d）では， $0.95 \mathrm{eV}$ およ び $1.15 \mathrm{eV}$ のピーク強度が, 基板内部のスペクトル（e) および熱処理前のスペクトル（f）よりも小さい。1.24 $\mathrm{eV}$ にピークを持つ発光は $\mathrm{Ga}$ 空孔-Si ドナー間遷移 $\left(\mathrm{Si}_{\mathrm{Ga}}{ }^{+} \mathrm{V}_{\mathrm{Ga}}{ }^{-}\right)^{12 \sim 14)}, 1.47 \mathrm{eV}$ の発光は $\mathrm{Si}$ ドナー $\mathrm{Si}$ アクセプ ター間遷移 $\left(\mathrm{Si}_{\mathrm{Ga}}{ }^{+} \mathrm{Si}_{\mathrm{As}}{ }^{-}\right)^{12,14,17)}$ による発光である。表面 側での $1.36 \mathrm{eV}$ の発光ピーク強度の增大および $1.47 \mathrm{eV}$ の発光ピークの出現は, 熱処理後に表面近傍での $\mathrm{V}_{\mathrm{As}}$ の 形成と内部への拡散および Si 原子の As サイトへの移動 による $\mathrm{Si}_{\mathrm{As}}$-の形成を示唆している。 $1.24 \mathrm{eV}$ の発光ピー クの出現自体は, 表面近傍での $\mathrm{V}_{\mathrm{Ga}}$ の形成および拡散が 


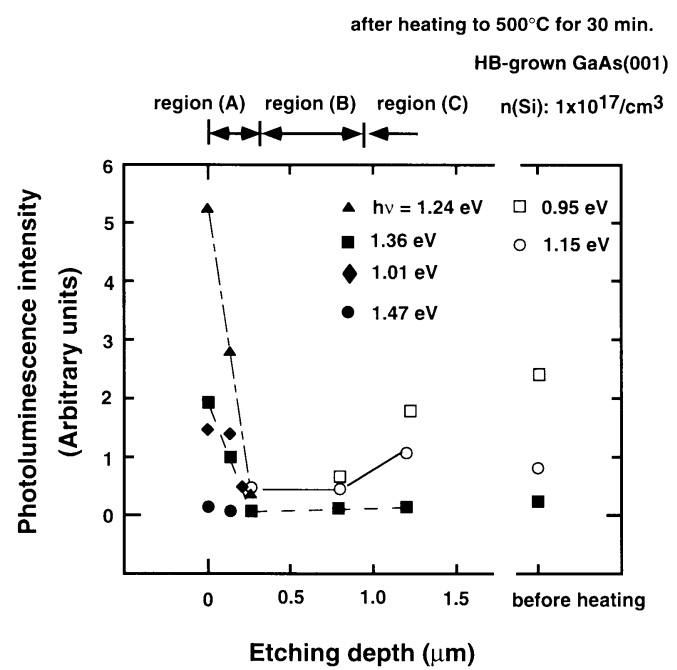

Fig. 3 The depth-profiles of photoluminescence-peak intensities for the DODIW-treated HB-grown GaAs(001) substrate $\left(\mathrm{n}(\mathrm{Si}): 1 \times 10^{17} / \mathrm{cm}^{3}\right)$ after heating to $500{ }^{\circ} \mathrm{C}$ for $30 \mathrm{~min}$.

生じていることを示している。 $1.01 \mathrm{eV}$ の発光ピークの 起源は不明である。

Fig. 3 は, Fig. 2 の各 PLピーク強度を深さ方向に再プ ロットしたものである。PLピークのエネルギー位置お よび強度により, 熱処理後, 基板は表面より 3 つの領域 に分けられる。region（A）は熱処理後の表面近傍の熱 劣化層領域であり, 1.24 および $1.36 \mathrm{eV}$ の強い発光強度 で特徴づけられる。この領域では, $1.01,1.47 \mathrm{eV}$ の発 光も顕著に認められる。region（C）は，未熱処理の基 板の発光スペクトルと同等の領域である。Fig. 3 で特徴 的な点は, region (B)の存在である。この領域では, 0.95 および $1.15 \mathrm{eV}$ の発光ピーク強度が region (C) よりも 小さい。低 $\mathrm{Si}$ ドープ基板 $\left(\mathrm{n}: 1 \times 10^{17} / \mathrm{cm}^{3}\right)$ では, この region (B) は, 表面から $0.3 \sim 0.8 \mu \mathrm{m}$ の領域に存在する。

Fig. 4 に, $600^{\circ} \mathrm{C}$ での熱処理後の PL ピーク強度の深 さ方向依存性を示す。Fig. 4 より, region（A）の 1.24 および $1.36 \mathrm{eV}$ の PL 発光強度が Fig. 3 の約 2 倍に增大 し，また region（A）の領域が表面から 1.0〜1.3 $\mu \mathrm{m}$ に 及んでいることがわかる。

各 PL スペクトルのピーク強度が結晶欠陥密度を反映 し，また各 PLピークが先に述べた欠陥に起因するなら ば，PL スペクトルの深さ依存性は，次のように解釈さ れる。Fig. 1 の表面近傍での $0.95 \mathrm{eV}$ および $1.15 \mathrm{eV}$ の PL

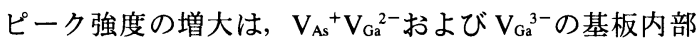

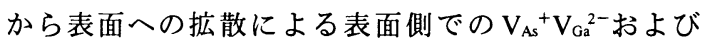
$\mathrm{V}_{\mathrm{Ga}}{ }^{3-}$ 密度の増大と理解される。また, Fig. 3 に見られる

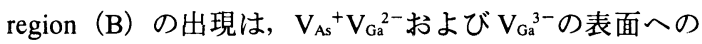

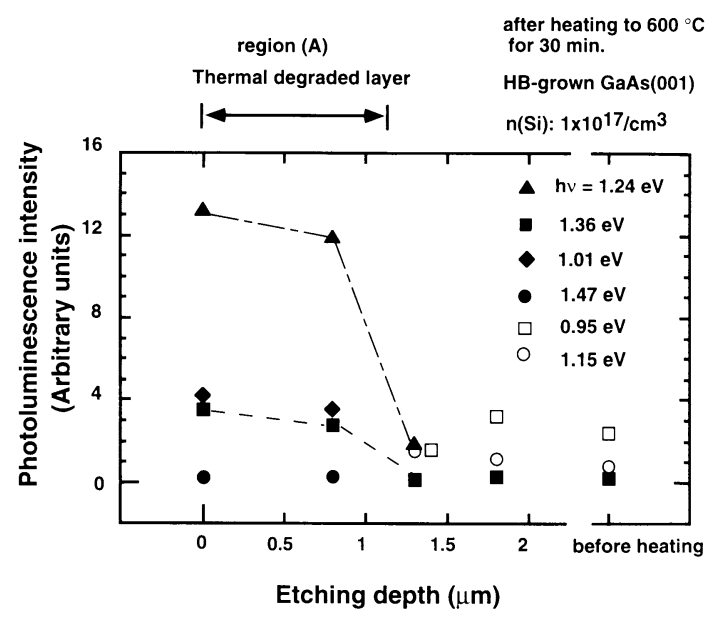

Fig. 4 The depth-profiles of photoluminescence-peak intensities for the DODIW-treated HB-grown GaAs(001) substrate $\left(\mathrm{n}(\mathrm{Si}): 1 \times 10^{17} / \mathrm{cm}^{3}\right)$ after heating to $600^{\circ} \mathrm{C}$ for $30 \mathrm{~min}$.

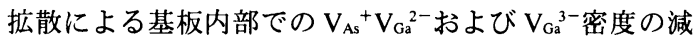

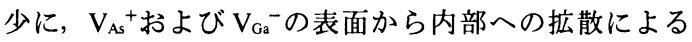
$\mathrm{V}_{\mathrm{As}}{ }^{+}$および $\mathrm{V}_{\mathrm{Ga}}{ }^{-}$密度の增大が重畳したものと考えられ

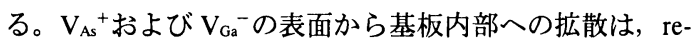
gion（A）の PL 発光強度および領域幅が熱処理温度 600 ${ }^{\circ} \mathrm{C}$ 基板で増大していることからも明らかである（Fig. 4)。 $V_{A s}$ 自体は表面からの砒素原子の熱脱離により, ま た $\mathrm{V}_{\mathrm{Ga}}$ は $\mathrm{V}_{\mathrm{As}}$ への $\mathrm{Ga}$ 原子の hopping より形成されたも のと考えられる ${ }^{18)}$ 。低 $\mathrm{Si}$ ドープ基板での $\mathrm{V}_{\mathrm{AS}} \mathrm{V}_{\mathrm{Ga}}$ の存在 および $500^{\circ} \mathrm{C}$ での表面近傍での $\mathrm{Ga}$ 空孔濃度の減少は, 陽電子消滅法の実験でも確認されている ${ }^{19211) 。 ~}$

\section{2 熱劣化層除去後の表面フェルミ準位の熱処理温 度依存性}

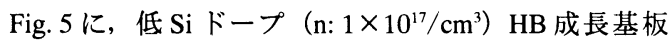
のSRPES 測定で得られた VB スペクトルの熱処理温度 依存性を示す。事前の熱処理は $500^{\circ} \mathrm{C}, 10$ 分間, エッ チング深さは $0.45 \mu \mathrm{m}$ である。最表面には, エッチング による region（B）の領域および DODIW 処理による過 剩砒素面が現われている。図中に, VBM の位置および $\mathrm{Au}$ 電極から求めた $\mathrm{E}_{\mathrm{Fs}}$ の位置を, 矢印および縦の実線 (零点) で示す。Fig. 5 より，VB スペクトルの強度およ び形状が, 室温 $350^{\circ} \mathrm{C}$ で変化し, また VBM の位置も 熱処理温度に依存していることがわかる。 $350^{\circ} \mathrm{C}$ 以下で のVB スペクトルの変化は, 主に DODIW 処理直後の表 面の過㮃砒素および吸着水分子（結合エネルギ一約 $6 \mathrm{eV}$ のピーク）の熱脱離による。

Fig. 6 は，VBM を基準に EFs を再プロットしたもので ある。図中には Fig. 5 以外のデータも記載してある。 sam- 


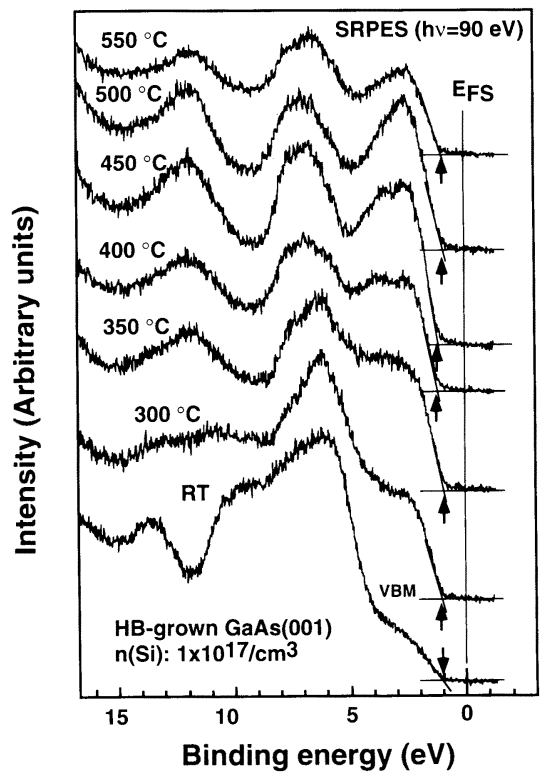

Fig. 5 Valence-band spectra of DODIW-treated GaAs(001) substrate after pre-heating to $500^{\circ} \mathrm{C}$ and etching depth of $0.45 \mu \mathrm{m}$. Arrows indicate the position of VBM. Vertical lines at $0 \mathrm{eV}$ indicates the position of surface Fermi level.

ple（a）は, Fig. 5 で示した基板（熱処理時間：10 分間, エッチング深さ : $0.45 \mu \mathrm{m}$ ), sample (b) は, $500^{\circ} \mathrm{C}$ で 30 分間熱処理した後， $0.7 \mu \mathrm{m}$ エッチングした試料である。 sample（c）は, DODIW 処理のみのリファレンス用 HB 成長基板である。 sample (d) は, VGF 成長基板 (n ( Si) : $\left.3 \times 10^{16} / \mathrm{cm}^{3}\right)$ を, $500^{\circ} \mathrm{C}$ で 30 分間熱処理した後，表面 より $0.6 \mu \mathrm{m}$ エッチングした試料である。

Fig. 6 より, DODIW 処理直後の $\mathrm{E}_{\mathrm{FS}}$ は, VBM から 1.02〜 $1.17 \mathrm{eV}$ にあるこがわかる。これは, Fig. 5 に示 した DODIW 処理直後の過剩砒素および水分子の吸着に よると考えられる。熱処理温度が $300^{\circ} \mathrm{C}$ に上昇するに 従い, 上記の吸着物の熱脱離により, sample (a), (b) および（d）の $\mathrm{E}_{\mathrm{Fs}}$ は，0.85〜 $1.02 \mathrm{eV}$ に移動する。熱処 理温度が $400 \sim 450^{\circ} \mathrm{C}$ では, EFs はVBM より $1.05 \sim 1.17$ $\mathrm{eV}$ となる。一方, sample（c）の $\mathrm{E}_{\mathrm{Fs}}$ は，吸着物の熱脱 離により熱処理温度の上昇に伴い，次第にミッドギャッ プ側に近づくものの，CBM 側への移動は見られず 400〜 $450^{\circ} \mathrm{C}$ でも $0.8 \mathrm{eV}$ にある。ここで特徴的な点は, 吸着 物の熱脱離後, sample（a)，(b) および（d）の $\mathrm{E}_{\mathrm{Fs}}$ が, sample（c）よりも常に CBM 侧にあることである。これ は，PL 測定の結果に基づくならば，低欠陥密度表面を 最表面とした場合には， $\mathrm{E}_{\mathrm{FS}}$ が CBM 側に移動し表面バ ンド曲がりの緩和（約 $0.2 \sim 0.37 \mathrm{eV}$ ）が生じることを示

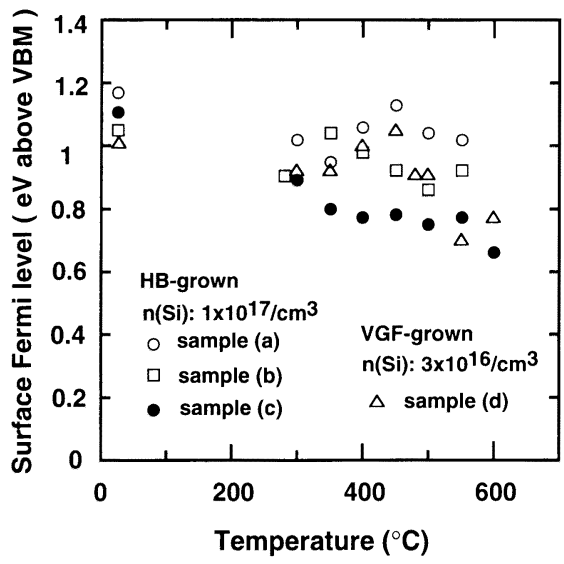

Fig. 6 The surface Fermi level position deduced from the VBM of the magnified VB spectra as a function of temperature. After DODIW, no oxides are detected on the surface by SRPES $\mathrm{Ga}$ and As 3d core levelspectra. Samples (a), (b), and (c) are HB-grown substrate $\left(\mathrm{n}(\mathrm{Si}): 1 \times 10^{17} / \mathrm{cm}^{3}\right)$. Sample (d) is VGF-grown one ( $\mathrm{n}(\mathrm{Si}): 3 \times 10^{16} / \mathrm{cm}^{3}$ ). Sample (a): with DODIW after pre-heating to $500^{\circ} \mathrm{C}$ for $10 \mathrm{~min}$ and etching in the depth of $0.45 \mu \mathrm{m}$, and sample (b): for $30 \mathrm{~min}$ and of $0.7 \mu \mathrm{m}$. Sample (c): with DODIW. Sample (d): for $30 \mathrm{~min}$ and of $0.6 \mu \mathrm{m}$.

している。熱処理温度が $500 \sim 550^{\circ} \mathrm{C}$ 以上では，表面近 傍での熱劣化の増大により， $\mathrm{E}_{\mathrm{FS}}$ はミッドギャップに漸 近する9)。

Fig. 7 に, 熱処理後の VGF 基板 (n $(\mathrm{Si}): 3 \times 10^{16} / \mathrm{cm}^{3}$ ) に対する， E ES とエッチング深さの関係を示す。事前の 熱処理温度および時間は, $500^{\circ} \mathrm{C} ， 30$ 分間である。 $\mathrm{E}_{\mathrm{FS}}$ の測定には, DODIW 処理時の過剩砣素の影響を取り除 くため, 高真空中で $450^{\circ} \mathrm{C}$ の加熱処理の後に行ってい る。Fig. 7 より， $\mathrm{E}_{\mathrm{FS}}$ がエッチング深さに依存し，表面 から $0.3 \mu \mathrm{m}$ エッチングした場合には, VBM より $0.8 \mathrm{eV}$ に在り, $0.6 \sim 1.0 \mu \mathrm{m}$ のエッチングでは $1.05 \sim 1.1 \mathrm{eV} に$ 移動することがわかる。表面より $1.4 \mu \mathrm{m}$ エッチングし た場合には, $\mathrm{E}_{\mathrm{FS}}$ は元の $0.8 \mathrm{eV}$ に戻る。この $\mathrm{E}_{\mathrm{FS}}$ が伝導 帯端に近づく領域は, region（B）の領域に対応してい る。なお，上記試料においても表面構造は，450～480 ${ }^{\circ} \mathrm{C}$ 以上で $1 \times 1$ から $2 \times 4$ 構造に変化した。

\section{4. 考察}

PL および SRPES 測定の結果は， 0.95 および $1.15 \mathrm{eV}$ のPLピーク強度が Ga 空孔に関連した欠陥の欠陷密度 に関係するならば,これらの結晶欠陥密度が減少すれば, EFS $\mathrm{GaAs}$ 結晶中の結晶欠陥の形成エネルギーの計算から, 


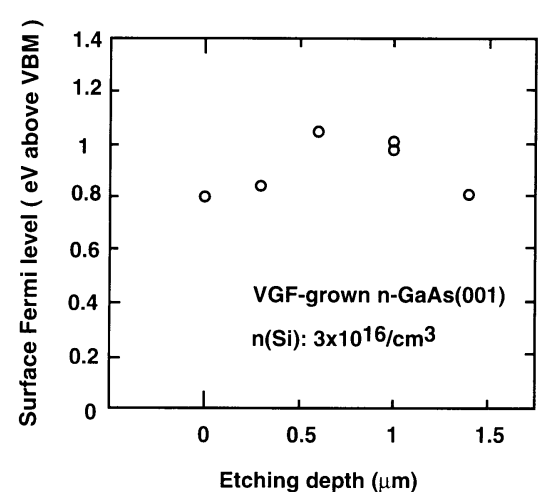

Fig. 7 Etching depth dependence of surface Fermi level position for the VGF-grown $\mathrm{GaAs}(001)$ substrate prepared by $500^{\circ} \mathrm{C}$-pre-heating. All data were obtained with SRPES at room temperature after heating to $450{ }^{\circ} \mathrm{C}$, chemical etching and DODIW treatment. The $450^{\circ} \mathrm{C}$ heating was done due to evaporate excess As and water molecules on the surface.

フェルミ準位の位置に対応し異なる荷電状態の欠陥が結 晶中に存在することを示した ${ }^{22)}$ 。Chen らは, Baraff らの 計算結果および両極性欠陥モデル23 26)を基に, 荷電状態 の Ga 空孔密度の分布状態および電荷中性条件を考慮し てフェルミ準位の位置と $\mathrm{Ga}$ 空孔密度の関係を求めた ${ }^{27}$ 。 Fig. 8 にその計算結果を示す。図中の gv は結晶中に含 まれる全結晶欠陥密度に対する荷電状態を考虑した全 $\mathrm{Ga}$ 空孔欠陥密度の割合である。ここでは, 全結晶欠陥 密度は一定と仮定している。Fig. 8より, フェルミ準位 の位置が gv に依存し, gv の減少に伴いフェルミ準位は CBM に漸近することがわかる。この計算結果は, 結晶 中の全 $\mathrm{Ga}$ 空孔欠陌密度が減少した場合, フェルミ準位 は, CBM 側に移動することを意味している。いま， 0.95 および $1.15 \mathrm{eV}$ の PLピーク強度の減少が $\mathrm{Ga}$ 空孔関連の 欠陌密度の減少を示し, また全欠陥密度が熱処理のエッ チング表面でも変わらないと仮定するならば, 本報告の $\mathrm{Ga}$ 空孔関連の欠陥密度の低下による表面フェルミ準位 の伝導帯端側への移動を, 上記のモデルを用いて説明で きる可能性がある。

高 $\mathrm{Si}$ ドープ基板では, 熱処理によるこのような PL ス ペクトルの変化および $\mathrm{E}_{\mathrm{FS}}$ の顕著な移動は認められな い。Fig. 9 に, HB 成長 GaAs $(001)$ 基板 $\left(\mathrm{n}(\mathrm{Si}): 5 \times 10^{17} /\right.$ $\left.\mathrm{cm}^{3}\right)$ の $500^{\circ} \mathrm{C}$ 熱処理後の PL スペクトルの深さ依存性 を示す。熱処理前の低 Si ドープ基板の PL スペクトル （: Fig.1のスペクトル (d)) と比較した場合, Fig. 9 の スペクトル（d）の $0.95 \mathrm{eV}$ および $1.15 \mathrm{eV}$ の発光ピーク 強度は, 2 倍および 12 倍に増大している。これは, PL ピーク強度が欠陥密度を反映しているならば, 高 Si ト

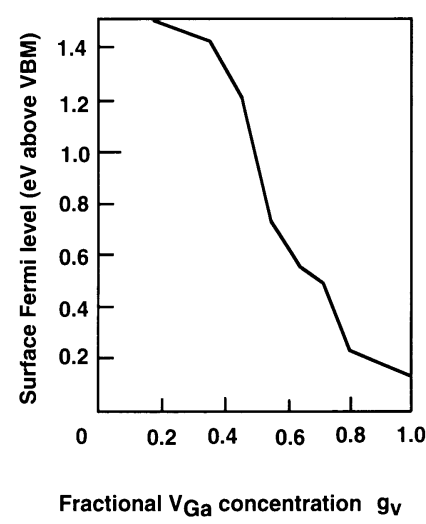

Fig. 8 The calculated Fermi level position as a function of fractional $V_{G a}$ concentration, $g_{v}$, for the amphotericdefect system $\mathrm{V}_{\mathrm{Ga}} /\left(\mathrm{As}_{\mathrm{Ga}}+\mathrm{V}_{\mathrm{As}}\right)$ with a total concentration of $1 \times 10^{18} / \mathrm{cm}^{3}$. The GaAs crystal is assumed to be undoped (see ref. 27).

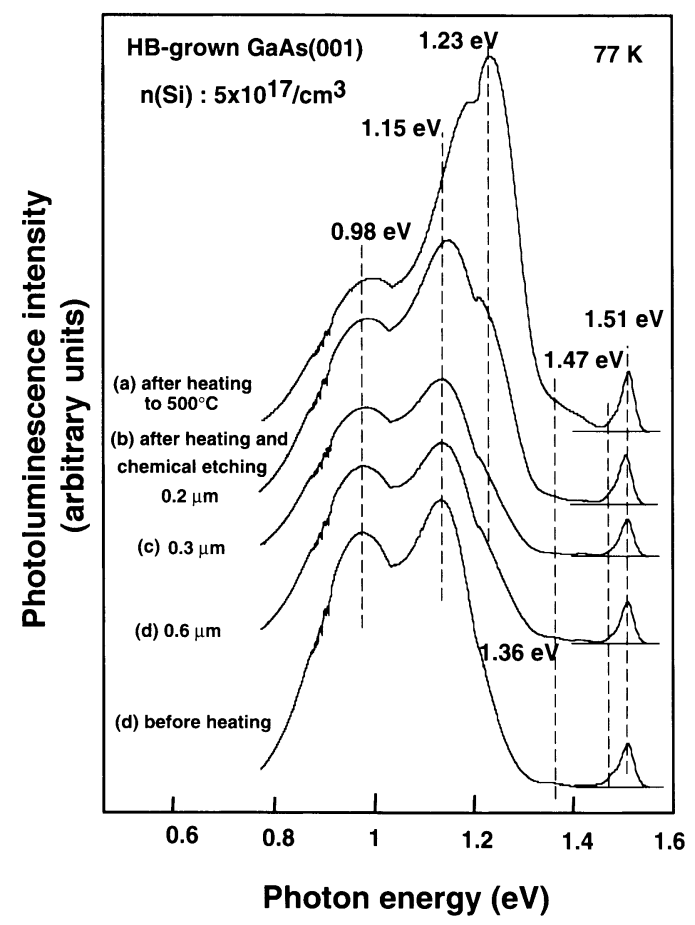

Fig. 9 The depth-profiles of photoluminescence-peak intensities for the DODIW-treated HB-grown GaAs(001) substrate $\left(\mathrm{n}(\mathrm{Si}): 5 \times 10^{17} / \mathrm{cm}^{3}\right)$ after heating to $500^{\circ} \mathrm{C}$ for $30 \mathrm{~min}$.

ープ基板では $\mathrm{Ga}$ 空孔に関連した欠陥密度が低ドープ基 板より高い事を示唆している20,28)。スペクトルの深さ依 存性では, 熱処理直後および表面側 ( : スペクトル (a), (b)）に熱劣化による $1.23 \mathrm{eV}$ の発光ピークが存在する 


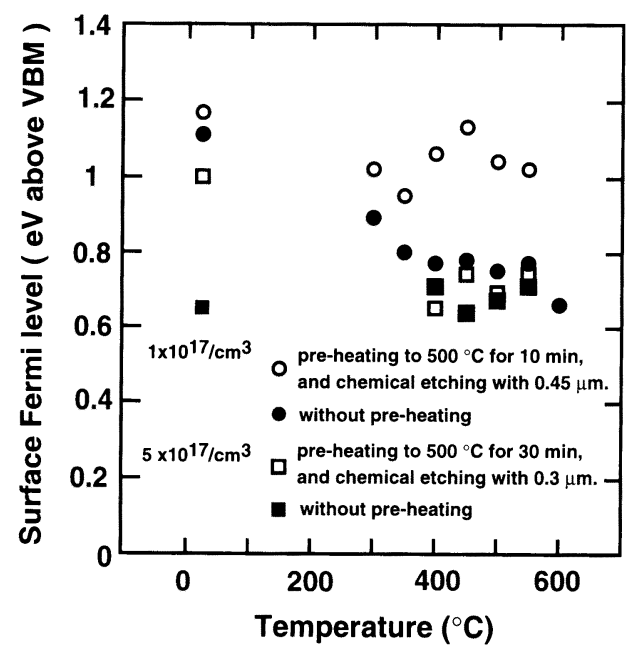

Fig. 10 The surface Fermi level position deduced from the VBM of the magnified VB spectra as a function of temperature for HB-grown substrate $\left(\mathrm{n}(\mathrm{Si}): 5 \times 10^{17} /\right.$ $\mathrm{cm}^{3}$ ). With DODIW after pre-heating to $500^{\circ} \mathrm{C}$ for 30 min and etching in the depth of $0.3 \mu \mathrm{m}(\square)$, and without pre-heating ( $\boldsymbol{\square})$.

ものの, 0.95 および $1.15 \mathrm{eV}$ の発光ピーク強度に大きな 滅少は認められない。

Fig. 10 に, 高ドープ基板の熱劣化層除去後（エッチ ング深さ $0.3 \mu \mathrm{m}$ ）の $\mathrm{E}_{\mathrm{FS}}$ の熱処理温度依存性を示す。比 較として, Fig. 6 中の sample（a）および (c) のデータ も併せて示す。Fig. 10 より, 高ドープ基板では, 熱劣 化層除去後の $\mathrm{E}_{\mathrm{FS}}$ の $\mathrm{CBM}$ 側への移動が見られず, また 末処理基板の $\mathrm{E}_{\mathrm{FS}}$ と, $400^{\circ} \mathrm{C}$ 以上でほぼ同一の值 (0.65 $0.75 \mathrm{eV})$ をとることがわかる。

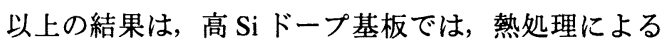

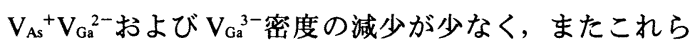
の欠陥密度が減少しない場合には, $\mathrm{E}_{\mathrm{FS}}$ が大きく変化し

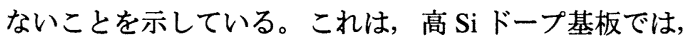
結晶成長時の $\mathrm{V}_{\mathrm{As}} \mathrm{V}_{\mathrm{Ga}}$ および $\mathrm{V}_{\mathrm{Ga}}{ }^{3-}$ の欠陷密度が大き く20,28)，また低ドープ基板より欠陥の拡散係数が小さい ため ${ }^{29)}$, EFs に対する結晶欠陥の減少の寄与が小さいた

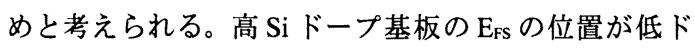
ープ基板より幾分 VBM 側にあること（0.65〜0.75 eV） も, 表面フェルミ準位のピンニング位置が表面近傍の $\mathrm{Ga}$ 空孔に関連した結晶欠陷密度に依存していることを支持 している。

\section{5.むす び}

本報告では, 脱溶存酸素 - 超純水洗浄処理の特徵を基 に, HB 成長および VGF 成長 GaAs（001）表面を例に，
表面近傍の結晶欠陥と表面フェルミ準位の関係をPL お よび SRPES 測定を用いて検討した。本報告で明らかと なった点を以下にまとめる。

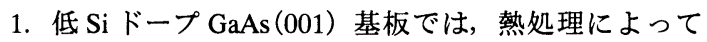
生じる熱劣化層直下に, 低欠陥密度の領域が存在す る。

2. この低久陥密度領域を最表面とした場合は, DODIW 処理時に生じた過剩 As 層の熱脱離後に表面フェル ミ準位は伝導体端側に移動しバンド曲がりの緩和 $(0.2 \sim 0.37 \mathrm{eV})$ が生じる。

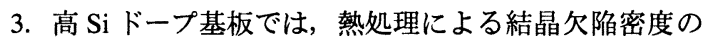
低減は認められず，また熱劣化層除去後の表面フェ ルミ準位の位置も大きく変化しない。

本報告では, PL 測定の結果を基に, 表面フェルミ準 位の位置が表面近傍の結晶欠陥密度に依存していること を示した。ただし, 今だ未解決の問題が残されている。 第一には, 表面フェルミ準位とフェルミ準位および表面 近傍の結晶欠陥密度を直接結び付ける理由を明らかにす る必要がある。これには, Chen らの計算結果が正しい

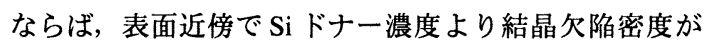
大きいことが必要となる。本報告では, 全結晶欠陥密度 を一定としたが, 熱処理後のエッチングによって表面近 傍において, 全 $\mathrm{Ga}$ 空孔欠陥密度に加え全結晶欠陥密度 も減少する場合には, フェルミ準位と全 $\mathrm{Ga}$ 空孔密度の 依存性を再検討する必要がある。

また, $0.95 \mathrm{eV}$ の発光ピークが $\mathrm{V}_{\mathrm{As}}{ }^{+} \mathrm{V}_{\mathrm{Ga}}{ }^{2-}$ に起因し, こ のピーク強度の減少が $\mathrm{V}_{\mathrm{As}}{ }^{+} \mathrm{V}_{\mathrm{Ga}}{ }^{2-}$ 密度の減少を意味する ならば, 表面近傍の電荷補償についても検討する必要が ある。これは $0.95 \mathrm{eV}$ の発光ピークがアクセプターとし て働き ${ }^{30)}, \mathrm{V}_{\mathrm{As}}{ }^{+} \mathrm{V}_{\mathrm{Ga}}{ }^{2-}$ 密度の減少は, キャリア一濃度の增 大をもたらす可能性があるためである。以上の問題は, 従来のドナー・アクセプター濃度に加え, 結晶欠陥密度, 結晶欠陥のエネルギー準位, および結晶欠陥準位のキャ リアーの占有確率, さらには非発光中心の結晶欠陥を含 めた表面近㥬の電荷中性条件の問題を検討する必要性を 示唆している。

\section{謝辞}

本研究の遂行にあたり, 有益な討論をしていただいた 筑波大学 谷川庄一郎教授, 並びに本研究遂行に対し激 励を頂いた上杉 直氏に感謝致します。また，日頃より 様々な問題点疑問点に対し有益な討論をしていただいた 高幣謙一郎, P. Kuniyil, 小林慶裕, 住友弘二, 福田常 男, 日比野浩樹, 尾身博雄の各氏に感謝致します。 


\section{文献}

1) Y. Hirota, M. Okamura, E. Yamaguchi and T. Hisaki: J. Appl. Phys. 65, 1328 (1989).

2) Y. Hirota and M. Okamura: Solid-State Electron. 33, Suppl. 437 (1990).

3) 廣田幸弘，本間芳和，杉井清昌，峰岸延枝 : 表面科 学 12, 381 (1991).

4) 廣田幸弘, 渡辺義夫, 福田常男, 住友弘二, 荻野俊 郎 : 表面科学 18, 232 (1997).

5) Y. Hirota: J. Appl. Phys. 75, 1798 (1994).

6) Y. Hirota, T. Ogino, Y. Watanabe and M. Oshima: Appl. Phys. Lett. 65, 2036 (1994).

7) Y. Hirota, T. Ogino, Y. Watanabe and M. Oshima: J. Vac. Sci. Technol. A 13, 1676 (1995).

8) Y. Hirota and T. Fukuda: Appl. Phys. Lett. 22, 2837 (1995).

9) Y. Hirota and K. Sumitomo: J. Appl. Phys. 79, 7785 (1996).

10) S. Chang, I.M. Vitomirov, L.J. Brillson, D.F. Rioux and M.H. Hecht: Phys. Rev. B 41, 12299 (1990).

11) M.H. Hecht: Phys. Rev. B 41, 7918 (1990).

12) L. Pavesi and M. Guzzi: J. Appl. Phys. 75, 4779 (1994).

13) H. Birey and J. Sites: J. Appl. Phys. 51, 619 (1980).

14) A. Amore Bonapasta, B. Bonanni, M. Capizzi, L. Cherubini, V. Emiliani, A. Frova and F. Sarto: J. Appl. Phys. 73, 3326 (1993).
15) M.A. Reshchikov, A.A. Gutkin and V.E. Sedov: Material Science Forum 196-201, 237 (1995).

16) A.A. Gutkin, N.S. Averkiev, M.A. Reshchikov and V.E. Sedov: Material Science Forum 196-201, 231 (1995).

17) A. Jorio, A. Wang, M. Parenteau, C. Carlone, N.L. Rowell and S.M. Khanna: Phys. Rev. B 50, 1557 (1994).

18) M. Bugajski, K.H. Ko, J. Lagowski and H.C. Gatos: J. Appl. Phys. 65, 596 (1989).

19) S. Dannefaer and D. Kerr: J. Appl. Phys. 60, 591 (1986).

20) Jong-Lam Lee, Long Wei, S. Tanigawa and M. Kawabe: J. Appl. Phys. 70, 674 (1991).

21) H.E. Evans, P.C. Rice-Evans, D.L. Smith, G.A. Gledhill and A.M. Moore: J. Phys. Condens. Matter 4, 1859 (1992).

22) G.A. Baraff and M. Schlüter: Phys. Rev. Lett. 55, 1327 (1985).

23) W. Walukiewicz: J. Vac. Sci. Technol. B 5, 1026 (1987).

24) W. Walukiewicz: J. Vac. Sci. Technol. B 6, 1257 (1988).

25) W. Walukiewicz: Appl. Phys. Lett. 54, 2094 (1989).

26) W. Walukiewicz: Phys. Rev. B 41, 10218 (1990).

27) C.-H. Chen and T.Y. Tan: Appl. Phys. A 61, 397 (1995).

28) Jong-Lam Lee, Long Wei, S. Tanigawa and M. Kawabe: J. Appl. Phys. 68, 5571 (1990).

29) Jong-Lam Lee, Long Wei, S. Tanigawa and M. Kawabe: J. Appl. Phys. 70, 674 (1991).

30) R. Toba, M. Warashina and M. Tajima: Material Science Forum 196-201, 1785 (1995). 